\title{
Malaria in American Troops in the South and Southwest Pacific in World War II
}

\author{
ROBERT J T JOY*
}

The control of infectious or communicable diseases generally demands in whole or in part management of the environment (water chlorination), law (immunization of school children), behaviour modification (safe sex), drugs (antibiotics, vaccines), and education or propaganda (television, posters).

The eventual control of malaria in the South Pacific (SOPAC) and Southwest Pacific Area (SWPA) theatres in World War II required the application in combat of all these variables. It is an exemplary tale of the importance of medical research before and during a war and-more importantly-of the absolute necessity of combat commanders understanding medical advice and applying it through the command chain with military discipline. The reduction of malaria cases is a multi-factorial process. Military personnel must take the prophylactic drugs, use insect repellent, observe clothing discipline, and use bed nets where possible. Dedicated engineering, entomological and preventive medicine units must determine the significant mosquito vectors and destroy their breeding places, define any reservoirs in native inhabitants, and educate troops and their commanders. Civil affairs and medical units must assist in the treatment of any native reservoirs and advise command on the use of native labour as a transmission risk.

Malaria was endemic to hyper-endemic in SOPAC and SWPA. It took three campaigns-Bataan, New Guinea and Guadalcanal-to demonstrate what a force destroyer this single disease was. As soon as combat commanders understood what a force multiplier malaria control could be, the resources and command support were given without stint.

This paper discusses the operational and medical aspects of malaria in American forces. The lessons apply equally to the Australian army; their story is splendidly told elsewhere. ${ }^{1}$ Of necessity, the tactical and operational background must be sketched in. Those soldiers and marines were not in the jungles by choice; it was a war that put them there, it was a war that exposed them to malaria, and it was a war that forced the application of peacetime knowledge, and wartime research that eventually solved the military medical problem.

\footnotetext{
*Robert J T Joy, Emeritus Professor, Department of Medical History, Uniformed Services University of the Health Sciences, Bethesda, MD 20814.

A shorter illustrated version of this paper was presented at a conference on 'The History of Malaria and War' on 6 May 1994 at the Wellcome Institute for the History of Medicine, London. I am indebted to Professor Roy M MacLeod for helpful suggestions about an early draft of the manuscript, and to Ms Kelly
}

Broscious for manuscript organization and preparation.

\footnotetext{
I Allan S Walker, The island campaigns, Australia in the War of 1939-45, series 5 (medical), Canberra, Australian War Memorial, 1957. The American equivalent is Medical Department, United States Army, Preventive medicine in World War II, vol. VI, Communicable diseases: malaria, eds John B Coates and Ebbe C Hoff, Washington, DC, Office of The Surgeon General, USGPO, 1963.
} 
The American army had last dealt with malaria during a war in its campaigns in the Philippines at the beginning of the twentieth century. ${ }^{2}$ In the United States, malaria had gradually disappeared except for vivax malaria ${ }^{3}$ in some areas of the rural South. ${ }^{4}$ The comments of Perrin Long, an experienced infectious disease and tropical medicine expert from Johns Hopkins, are worth citing. "The majority of physicians entering the Armed Forces had had practically no experience in the diagnosis or treatment of malaria. The average younger American physician, except in certain rural areas in the Southern United States, hardly gave a thought to malaria and was unconcerned about his lack of knowledge of this disease". ${ }^{5}$ In short, few American physicians had any experience with the disease, even those in the regular army.

\section{Bataan}

The great disaster of American armies in the Philippines in early 1942 was due in part to General Douglas MacArthur's last minute change in operations that led to the previously planned but now hastily extemporized retreat to Bataan. ${ }^{6}$ That peninsula was known to be a major reservoir of malaria. The Philippines were estimated to have one to two million cases at all times. Incomplete data for 1938 recorded 76,193 new cases with 9,427 deaths. $^{7}$ On Bataan, quinine was in short supply and used only for treatment; the nature of the terrain prevented the application of mosquito control measures, and command direction of personnel protection was not enforced. Malaria and dysentery, coupled with starvation and lack of supplies and reinforcements, led to the inevitable surrender on 9 April 1942 of a sick and starving army deprived of the bare necessities required for survival, to say nothing of combat. ${ }^{8}$

\footnotetext{
2 Mary C Gillett, The Army Medical Department, 1865-1917, Washington, DC, Center of Military History, USGPO, 1995, pp. 201-20.

${ }^{3}$ There are four Plasmodium species of clinical interest; of these only two-vivax (relatively benign) and falciparum (relatively malignant)-are of major importance. Drug resistance has become more and more common in falciparum, less so in vivax. Both are transmitted by various species of the female Anopheline mosquito. For further detail see, Mary Pudney, 'Antimalarials: from quinine to atovaquone', in P A Hunter, G K Darby and N J Russell (eds), Fifty years of antimicrobials: past perspectives and future trends, Cambridge University Press, 1995, pp. 229-47. For a general discussion of malaria, see G Thomas Strickland, 'Malaria', in G Thomas Strickland (ed.), Tropical medicine, Philadelphia, W B Saunders, 1991, pp. 586-617.

${ }^{4}$ Erwin H Ackerknecht, Malaria in the upper Mississippi valley, 1760-1900, Baltimore, Johns Hopkins Press, 1945; Ernest C Faust, 'Clinical and public health aspects of malaria in the United States from a historical perspective', Am. J. Trop. Med., 1945, 25: 185-201.

5 Perrin H Long, 'Treatment of malaria', in Medical Department, United States Army, Internal medicine in World War II, vol. II, Infectious diseases,
}

eds John B Coates and W Paul Havens, Jr, Washington, DC, Office of the Surgeon General, USGPO, 1963, p. 493.

${ }^{6}$ See Gavin Long, MacArthur as military commander, New York, Van Nostrand, 1969, for an overview; for detailed discussion see Louis Morton, The fall of the Philippines, Washington, DC, Office of the Chief of Military History, Dept. of the Army, USGPO, 1953, pp. 161-89. A critical view is in Stanley L Falk, 'Douglas MacArthur and the war against Japan', in William L Leary, We shall return! MacArthur's commanders and the defeat of Japan, Louisville, University Press of Kentucky, 1988, pp. 1-22.

${ }^{7}$ Paul F Russell, Malaria and culicidae in the Philippine Islands, Manila, Bureau of Printing, 1934. For later data, see James S Simmons, Tom F Whayne, Gaylord W Anderson, and Harold M Horack, Global epidemiology, Philadelphia, Lippincott, 1944, vol. I, p. 414. ("Spleen rate" means examining people for enlarged spleens which are attributed to chronic malaria-true in nearly all cases.)

${ }^{8}$ Mary Ellen Condon-Rall, 'U.S. Army medical preparations and the outbreak of war: the Philippines, 1941-6 May 1942', J. mil. Hist., 1992, 56: 35-56. 
Robert J T Joy

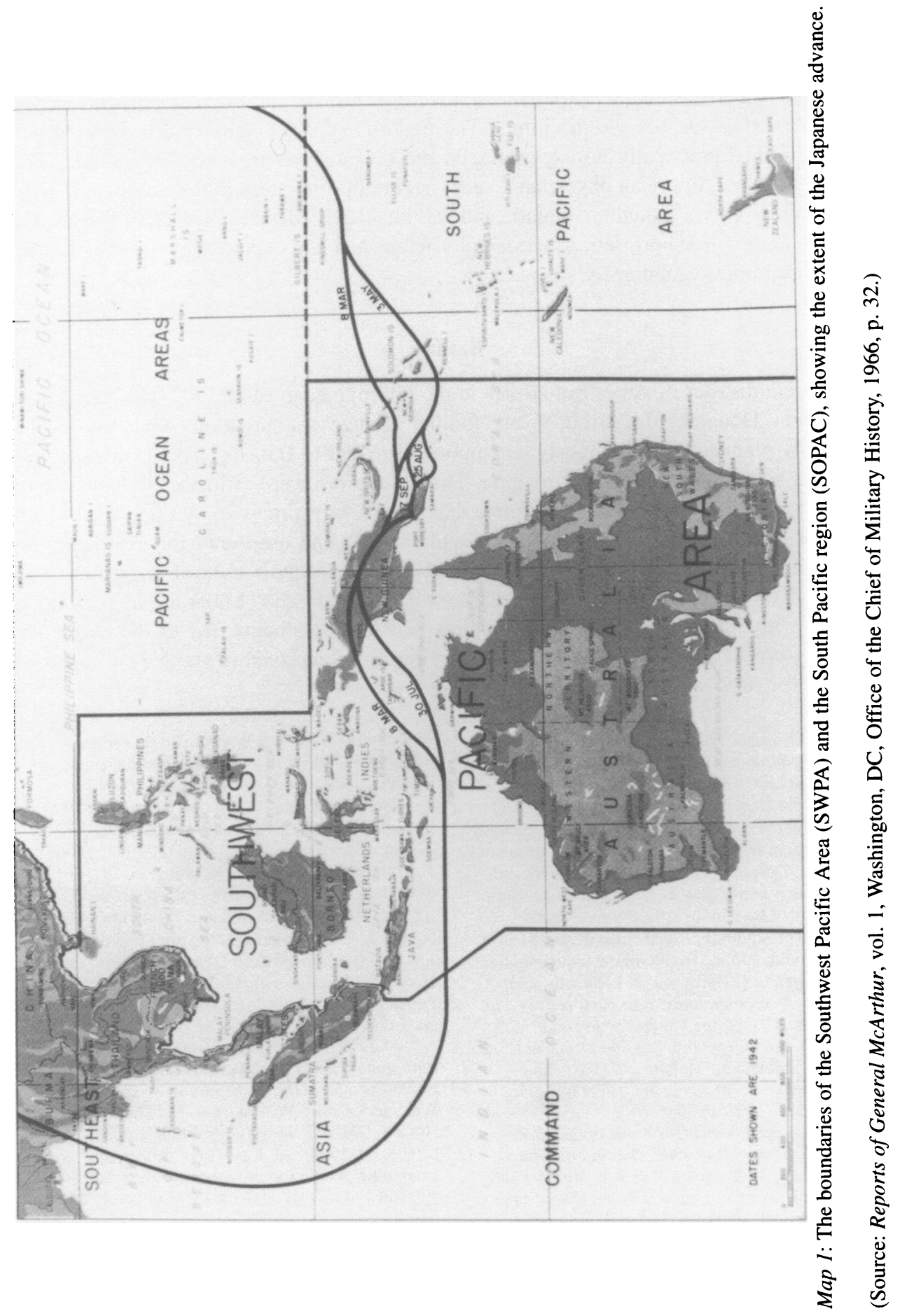


Malaria in American Troops in World War II

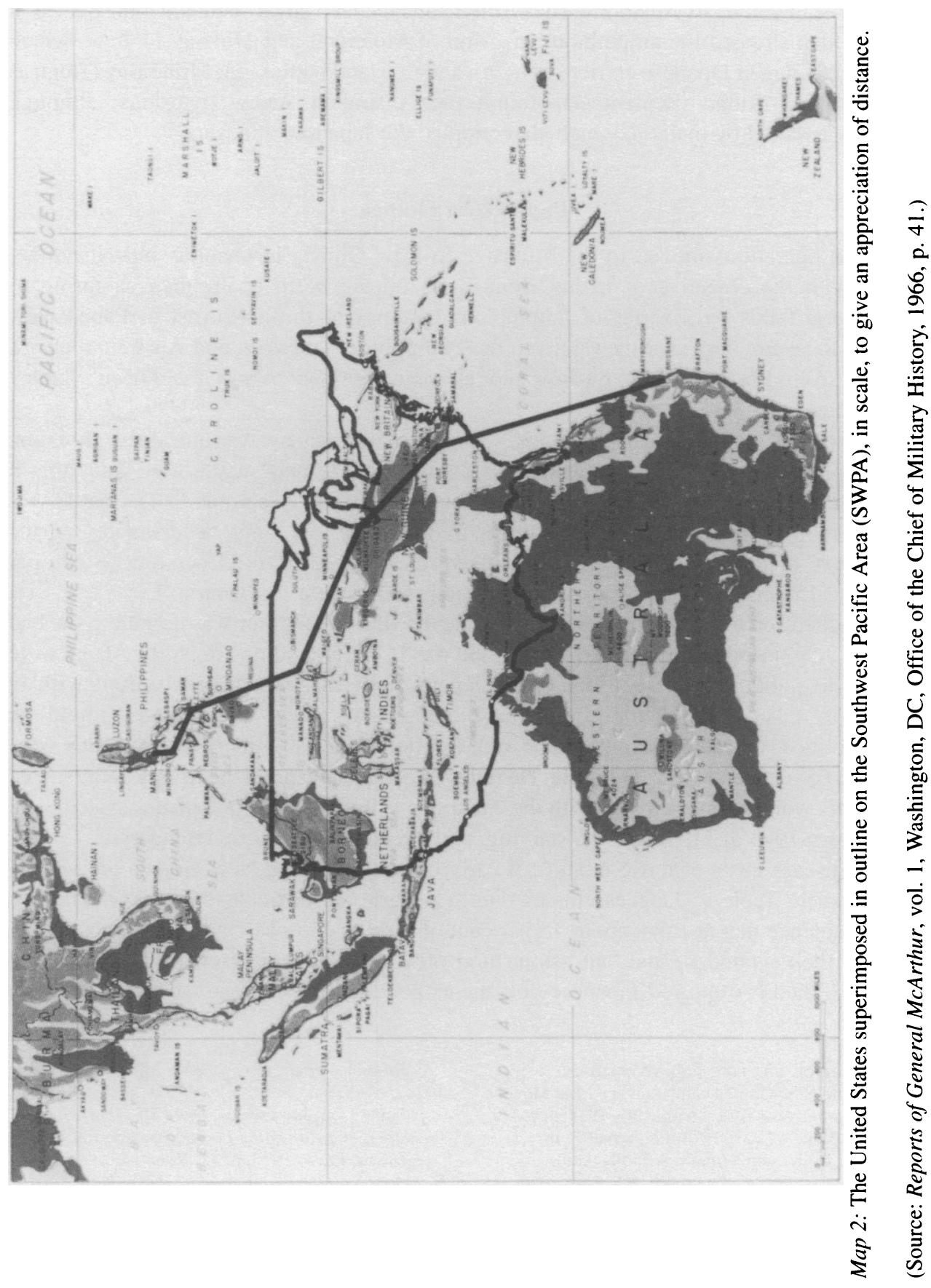


MacArthur had escaped to Australia in March of 1942 and had assumed command of allied forces in the Southwest Pacific Area. The Japanese made four attempts to seize Port Moresby on the southern coast of New Guinea for use as a staging base to stop the flow of American forces to Australia. Two American-Japanese naval battles, Coral Sea (4-8 May, which stopped the amphibious invasion of Moresby) and Midway (4 June, which severely damaged Japanese carrier strength), and two land battles-at Milne Bay (August) and at Imita Ridge (September)—found the Australian Army victorious, although severely assailed by malaria, which also crippled the Japanese attackers. ${ }^{9}$

\section{Papua New Guinea}

Allied operations moved to the offensive in New Guinea in October and November 1942, with the objective of taking Buna-Gona on the north coast, then capturing or building airfields by a series of amphibious landings to the northwest in Papua New Guinea to secure bases for the return to the Philippines. American and Australian troops moved from Port Moresby by sea and air and overland across the Owen Stanley mountains.

The battle was a "near-run thing" for the Americans. An untrained division, incompetent and unskilled leadership, bad intelligence, and jungle-wise and dug-in Japanese defenders all presented obstacles that were barely overcome. ${ }^{10}$ The battle was fought in a malaria hyper-endemic area. While there can only be estimates of the prevalence of malaria in New Guinea, spleen rates ranged from 25 per cent to 100 per cent, and 15 per cent of non-native hospital admissions were for malaria. ${ }^{11}$

The allied force was nearly destroyed by the disease. MacArthur was desperate (he had already announced an immediate victory and the TORCH landings in North Africa were getting the publicity). He sent Lieutenant General Robert L Eichelberger to Buna with an order "to take Buna or not come back alive". At Buna, Eichelberger found an undisciplined, defeated, dispirited, and sick division. The 200-man rifle companies were down to 65 men, and all were febrile. He relieved officers, inspired the troops, reorganized the battle, worked more closely with the Australians, invigorated the logistics system, and by January 1943 had defeated the starving, malaria-ridden Japanese defenders. ${ }^{12}$

The disease costs of those months of early combat in Papua New Guinea are vividly illustrated in Table 1. Japanese losses due to malaria are difficult to quantify. There is some evidence that at Buna about 45 per cent of their malaria cases died, perhaps 55 per cent of their wounded, and "an astonishing $60 \%$ of their patients with dysentery and enteritis" died. ${ }^{13}$ Captured Japanese documents permit some comparison with American

\footnotetext{
${ }^{9}$ Walker, op. cit., note 1 above, pp. 6-57.

${ }^{10}$ For the New Guinea campaign see Lida Mayo, Bloody Buna, New York, Doubleday, 1974; Jay Luvaas, 'Buna: a Leavenworth nightmare', in Charles E Heller and William A Stofft (eds), America's first battles, Lawrence, KS, University Press of Kansas, 1986, pp. 186-225, and Samuel Milner, Victory in Papua, Washington, DC, Office of the Chief of Military History, Dept. of the Army, USGPO, 1957.
}

\footnotetext{
${ }^{11}$ Simmons, et al., op. cit., note 7 above, pp. 402-3.

${ }^{12}$ Quote from Jay Luvaas, Dear Miss Em: General Eichelberger's war in the Pacific, Westport, CN, Greenwood Press, 1973, p. 32; Robert L Eichelberger, Our jungle road to Tokyo, New York, Doubleday, 1950, pp. 2-44.

${ }^{13}$ Albert E Cowdrey, Fighting for life: American military medicine in World War II, New York, Free Press, 1994, p. 76.
} 
Malaria in American Troops in World War II

Table 1

Casualties in Papua New Guinea

Troops

Tropical Diseases

Malaria

Battle Casualties

\begin{tabular}{lrrr}
\hline Australian & 29,101 & 21,600 & 6,154 \\
American & 8,259 & 6,292 & 1,598 \\
Total & 37,360 & 27,892 & 7,752
\end{tabular}

These data are for 1942, including the Milne Bay, Owen Stanley and Buna campaigns. it is clear that the Australians bore the brunt of the fighting. Overall, tropical diseases were 4.8:1 to battle casualties with the malaria ratio $3.6: 1$.

(Source: Allan S Walker, The island campaigns, Australia in the War of 1939-45, series 5 (Medical), Canberra, Australia War Memorial, 1957, pp. 121-2.)

Forces in February 1943. The Japanese on Rabaul (not fighting) had a malaria rate of $1,440 / 1000 / y e a r$ compared with the US rate of $718 / 1000$ in New Guinea. Total Japanese hospital admissions for malaria were $4,086 / 1000$ in contrast to about $2,000 / 1000$ for the Americans. ${ }^{14}$

\section{Guadalcanal}

There had been another battle occurring while the New Guinea battles were raging. In July 1942, intelligence surveys revealed that the Japanese were building an airfield on Guadalcanal in the Solomon Islands group. If it were allowed to become operational, the Japanese would be able to block the sea lanes between the United States and Australia. This area was under United States Navy command and was called the South Pacific Area (SOPAC). Aircraft under MacArthur's SWPA air force collaborated in support of the fight for Guadalcanal.

On 7 August 1942, the First Division of the United States Marine Corps made an unopposed landing on Guadalcanal and secured the airfield. For the next seven months marine and army units would receive ferocious attacks from reinforced Japanese forces and the Japanese navy would essentially dominate the surrounding sea for several months. ${ }^{15}$

Once again, the choice of a battle area was in malaria hyper-endemic terrain. As in New Guinea, the prevalence of malaria before the war can only be estimated. In Guadalcanal spleen rates averaged about 80 per cent and between 10 and 20 per cent of hospital admissions were for malaria. ${ }^{16}$

\footnotetext{
14 Thomas A Hart and William H Hardenbergh, 'The southwest Pacific area', in Preventive medicine in World War II, op. cit., note 1 above, pp. 573-5.

15 Richard B Frank, Guadalcanal: the definitive account of the landmark battle, New York, Random House, 1990, is the best recent military and naval
}

\author{
history. See also, John Miller, Jr, Guadalcanal: the \\ first offensive, Washington, DC, Office of the Chief \\ of Military History, Dept. of the Army, USGPO, \\ 1949. \\ ${ }^{16}$ Simmons, et al., op. cit., note 7 above, p. 451.
}




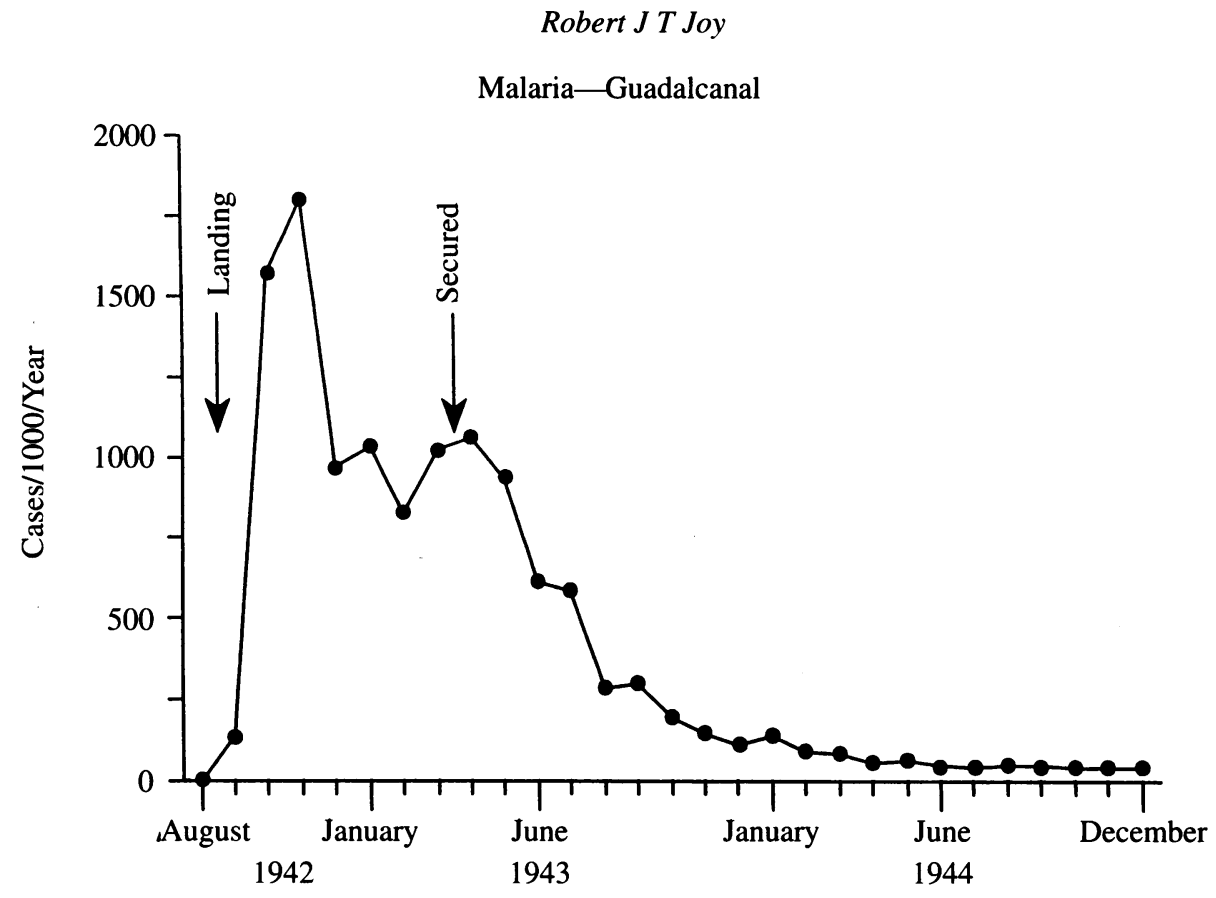

Figure 1: Malaria admission rates on Guadalcanal for Marine and army forces.

(Source: Paul A Harper, et al., 'New Hebrides, Solomon Islands, Saint Matthias Group and Ryukyu Islands', in Medical Department, United States Army, Preventive medicine in World War II, vol. VI, eds John B Coates and Ebbe C Hoff, Washington, DC, Office of the Surgeon General, 1963.)

Malaria was the single most serious and common cause of morbidity. By November over 12 per cent of the marine division was ineffective from malaria, soon with a rate of over 1500/1000/year. Major General Alexander Vandegrift, the division commander, issued an "informal" order that no Marine would be excused from the line or patrol unless his temperature was greater than $103^{\circ} \mathrm{F}^{17}$

The Japanese finally evacuated the island in early February 1943; except for mopping up holdout survivors, Guadalcanal had been taken. Japanese losses to malaria are again difficult to quantify. On Guadalcanal, their logistic system collapsed and the troops starved. By the time they evacuated the island, about 65 per cent of their total estimated force $(33,600-44,000)$ was dead. Perhaps 30 per cent died of disease-malaria, dysentery, beriberi, and starvation. ${ }^{18}$

\footnotetext{
${ }^{17}$ Frank O Hough, Verle E Ludwig and Henry I Shaw, Jr, History of U.S. Marine Corps operations in World War II: Pearl Harbor to Guadalcanal, Washington, DC, HQ US Marine Corps, USGPO, 1958 , vol. 1, p. 359. See also, The history of the Medical Department of the United States Navy in
}

World War II, Washington, DC, US Government Printing Office, 1953, vol. I, p. 73.

${ }^{18}$ Frank, op. cit., note 15 above, pp. $338,354,527$, $588,613-14$. See also, Miller, op. cit., note 15 above, pp. $155,159$. 
Given the Japanese expertise in medical research up to the 1930s and their excellent military medical care in the Russo-Japanese War of 1904-1905 ${ }^{19}$ one can only speculate about the reasons for their poor military medical record in World War II. Perhaps the Bushido indoctrination of the 1930s included an indifference to medical support as part of the larger indifference to survival (the Banzai charge, the Kamikaze attacks) - suicide rather than surrender.

Thus in three important battles malaria was a major cause of manpower loss, in the last two the defeat of the enemy was by no means assured, and (in ironic counterpoint to Bataan) malaria and starvation eventually destroyed the Japanese forces.

\section{Command Responses}

The impact of malaria brought to commanders a new understanding of their role in its control. Probably the first to recognize this was General Sir Thomas Blaney, Commanderin-Chief of the Australian Army, during the Owen Stanley Campaign of June to September 1942. ${ }^{20}$ In September 1942, he sent Colonel Neil H Fairley, RAAMC and a tropical medicine and malaria expert, to head a mission to the United States and England. The need for drugs, netting, insect repellents, malaria control personnel, supplies and equipment was forcefully presented. In the United States especially, measures were taken to respond to these requests. ${ }^{21}$

Early in the Guadalcanal campaign, no attention was paid to malaria control and there was essentially no malaria discipline. "The prevailing attitude was expressed by one high ranking officer who said-we are here to kill Japs and to hell with mosquitoes". ${ }^{22}$ But in November 1942, Admiral William F Halsey, Jr, the new Commander SOPAC, began to introduce small malaria control units. Because of the continuous heavy fighting, they could work initially only in a very limited rear area. More important was Halsey's directive of 13 November 1942 on the use of such units: ". . . Commanders of all bases . . . are enjoined to cooperate to the fullest extent with the officer in charge of Malaria Control Units ....". The order further required consultation about "the selection of sites for camps and airfields". Continued problems with malaria control led to a stronger directive on 24 September 1943. “. . . Island Commanders . . . will require subordinate units to carry out prescribed control measures ....'. In short, Halsey's attention had been captured and precise orders went down the chain of command. ${ }^{23}$

When Eichelburger returned to Australia in January 1943 to command and train new divisions, he lectured his new commands on the lessons of Buna where lack of enforcement of discipline was "one of the most glaring causes of failure". He believed that

\footnotetext{
${ }^{19}$ See, for example, Charles Lynch, MC, USA, Reports of military observers attached to the armies in Manchuria during the Russo-Japanese War, Washington, DC, USGPO, 1907; Louis J Seaman, The real triumph of Japan, New York, Appleton, 1909.

${ }^{20}$ For an excellent account of disease on the Kokoda Trail, see H D Steward, Recollections of a regimental medical officer, Melbourne University Press, 1983. Walker, op. cit., note 1, above, pp. 14-37.
}

${ }^{21}$ Walker, op. cit., note 1 above, p. 162; Hart and Hardenbergh, op. cit., note 14 above, p. 540.

22 Quote from, Paul A Harper, Wilbur G Downs, Paul W Oman, and Norman Levine, 'New Hebrides, Solomon Islands, Saint Matthias Group and Ryukyu islands', in Preventive medicine in World War II, op. cit., note 1 above, p. 426; Frank, op. cit., note 15 above, p. 260.

${ }^{23}$ Harper, et al., ibid, pp. 435-7. 
"nothing important can be left to the individual inclination of the soldier. The taking of quinine, the care of insect bites . . . shaving and bathing, avoidance of sleeping on the ground are all subjects about which specific instructions must be issued and diligently enforced". 24

MacArthur, on recommendations from Australian and American medical officers, had established a Combined Advisory Committee on Tropical Medicine, Hygiene and Sanitation in March 1943, reporting directly to his General Headquarters, SWPA. It was agreed that Fairley, as the most knowledgeable person, would chair the committee. The committee began to sponsor research, define problem areas, and prepare directives on disease control which MacArthur endorsed and issued. ${ }^{25}$ It should be noted that this was a staff committee. It had no direct authority over malaria control operations and its statistical information was only that which could be provided by its members, all of whom held other senior and critical jobs. ${ }^{26}$

In May 1943, MacArthur was briefed on the malaria incidence by Colonel Paul F Russell, MC, the American army malaria consultant. MacArthur's response was clear, "Doctor, this will be a long war if for every division I have facing the enemy, I must count on a second division in hospital with malaria and a third division convalescing from this debilitating disease". ${ }^{27}$

General George C Kenney, MacArthur's Air Commander, responding to medical advice on the protective wearing of clothing in November 1942, ran an experiment-one squadron clothed in long trousers and long sleeved shirts and one squadron in shorts and short sleeved shirts. At the end of a month there were two cases of malaria in the long sleeve/trouser squadron and 62 cases in the other. This convinced Kenney and his troops, "I put out an order requiring everyone in the Fifth Air Force to wear long trousers and long sleeves. The evidence was good enough for the kids as well as me". ${ }^{28}$

General George C Marshall, the magisterial Chief of Staff of the United States Army in July 1943 evaluated the resource and command problems as related to the disease losses of the New Guinea and Guadalcanal campaigns. "Apparently the trouble in the past has been that priorities for munitions overrode those for the necessary screening and other material to provide protection at the bases, also there has not been sufficiently rigid sanitary discipline as to the individual soldier." 29 That cogent statement neatly summarizes the issues.

Thus, by mid-1943, senior army, navy, and air force commanders understood the problem, had arranged for competent medical advice, had asked for medical help and had issued appropriate orders about malaria control. That was half of the solution.

\footnotetext{
24 Jay Luvaas and John F Shortal, 'Robert L Eichelberger: MacArthur's fireman', in Leary, op. cit., note 6 above, p. 1-22.

${ }_{25}$ Mary Ellen Condon-Rall, 'Allied cooperation in malaria prevention and control: the World War II in the Southwest Pacific experience', J. Hist. Med. Allied Sci., 1991, 46: 493-513; Hart and Hardenbergh, op. cit., note 14 above, p. 540; Allan S Walker, Clinical problems of war, Medical Series, Australia in the War of 1939-45, Canberra,

Australian War Memorial, 1952, p. 99.
}

\author{
${ }^{26}$ Blanche B Armfield, Medical Department, \\ United States Army, organization and administration \\ in World War II, Washington, DC, Office of the \\ Surgeon General, USGPO, 1963, pp. 443-5. \\ ${ }^{27}$ Paul F Russell, 'Introduction', in Preventive \\ medicine in World War II, op. cit., note 1 above, p. 2. \\ ${ }^{28}$ George C Kenny, General Kenny reports, New \\ York, Duell, Sloan and Pearce, 1949, p. 125. \\ ${ }^{29}$ Armfield, op. cit., note 26 above, p. 442 .
}




\section{Medical Responses}

Beginning in 1940, there was pre-war planning by the army for mosquito vector control (especially in the United States); for medical intelligence about malaria in potential combat areas; for the development of malaria control teams; for training of malariologists and the education of line officers and troops, and for the development of a civilian research programme seeking new drugs for prophylaxis and treatment. ${ }^{30}$

Those programmes directly under medical control (research, medical training, etc.), began to be implemented. ${ }^{31}$ Those that required outside support for personnel, money and equipment were progressing very slowly when the Japanese attack on Pearl Harbor on 7 December 1941 precipitated a half-ready United States into war. All attention was now given to arms and combat troops and combat commanders had no time for mosquitoes.

In spite of Colonel Simmons' post-war statements, the suddenness of the Japanese assault success in the SWPA and SOPAC in their choice of battlegrounds, and Allied organizational unpreparedness and confusion meant that line commanders focused first on war fighting capability. Although the SWPA asked for malaria control units in December 1942 , those units were not ready until early 1943 . Thus effective malaria control measures did not begin until mid-1943. For example, malariologists and malaria control units did not reach New Guinea until March 1943. The pre-war planning had assumed that the theatre malariologist would be directed by a theatre surgeon reporting directly to the theatre commander. MacArthur, however, had assigned his theatre surgeon to the Services of Supply and there was no single medical directing authority for malaria control; the medical staff was split between logistical and command staffs until January 1944. Even so, by August 1944, there were 18 malariologists, 32 survey and 55 control units in the theatre although there was still no overall medical command of these units. ${ }^{32}$

In SOPAC, a small Malaria and Insect Control Organization was established in November 1942, headed by a Navy medical officer with pooled resources from the Army and the Navy. From the beginning, the medical officers in charge reported directly to the area commander at all levels of the command chain. Initially, a Navy medical officer was in charge; later in the war as the marines moved to the Central Pacific islands, army medical officers directed the programme. It remained a true joint programme-the senior army medical officer noted, "the efficiency and economy of this joint use of personnel and equipment is a stimulating chapter in combined service organization". In contrast to the divided authority and organizational chaos of MacArthur's direction of medical staffing, the malaria control work in SOPAC worked smoothly. ${ }^{33}$

The malaria control organizations had been approved by the War Department General Staff in October 1942, and offered by the Surgeon General to theatre commanders that month. The organization consisted of: a medical officer malariologist as supervisor; a survey unit (an entomologist, a parasitologist, 11 enlisted technicians); a control unit (a sanitary engineer and 11 enlisted technicians); locally recruited labour gangs to do control

\footnotetext{
30 James S Simmons, 'The malaria control program of the United States Army during World War II', in Proceedings of the Fourth International Congress on Tropical Medicine and Malaria, Washington, DC, USGPO, 1948, vol. I, pp. 827-40.

${ }^{31}$ Mary Ellen Condon-Rall, 'The role of the U.S.
}

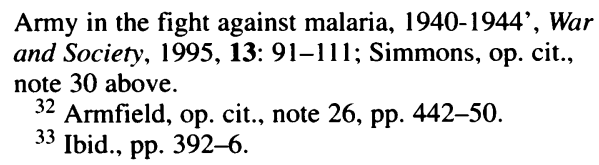


work, and local area anti-malaria squads of enlisted men for control work in their troop units.

The survey unit determined the malaria species present, defined the predominant vectors, assessed the malaria rates in native populations, and did troop and command education. The control unit directed the drainage, oiling, spraying and other destruction of breeding sites, and trained the labour gangs. A typical organization is given in Table 2.

Personnel training and the assembly of equipment and supplies were complete by January 1943, and the units began to be shipped to both theatres. Table 3 illustrates the build up of units in SWPA and SOPAC. ${ }^{34}$ Control of the mosquito vectors in non-combat areas was done by drainage and ditching to remove breeding sites, by oiling such sites to kill larvae and by the use of bed nets and screening. Base and airfield sites were located away from native villages, to avoid them as reservoirs. In a few cases, the villages were moved if the combat units could be placed at a sufficient distance. These were all well established techniques used for years. There were three new technologies introduced in World War II-DDT, the "bug bomb", and DEET insect repellent.

DDT (Dichloro-diphenyl-trichloroethane) had been synthesized in 1874 by Othnian Zeidler in Vienna as a problem in organic synthesis. Paul Muller of Geigy Laboratories in Switzerland re-synthesized it in 1939 and discovered it was a versatile and powerful insecticide. It was marked in 1940 as Gerasol, an agricultural pesticide and lousicide. ${ }^{35}$ In October 1942, it was tested by the US Department of Agriculture Bureau of Entomology and Plant Quarantine at its laboratory in Orlando, Florida, as a larvicide, and as a spray for immediate and residual effects as an adult mosquito killer. ${ }^{36}$ It entered the Army supply list in May 1943 and reached the combat theatres in late 1944. It should be noted that the decrease in malaria rates was not due to the advent of DDT-it arrived too late to have a significant impact. ${ }^{37}$

The aerosol dispenser, "bug bomb", was developed by the USDA Orlando laboratory in 1941. It was a one pound steel container with pyrethrum oil spray dispersed by Freon12 propellant. Extraordinarily useful for killing mosquitoes in closed environments, inside bed nets, and in aircraft, one bomb would treat 150,000 cubic feet of space. About 35 million were issued during the war. ${ }^{38}$

Repellent testing of new compounds began in 1941 at the Army's request at the USDA Orlando laboratory with screening of new compounds from industrial and academic laboratories. Over 7,000 compounds and mixtures were screened. The final product sent to the field was a mixture of dimethyl phthalate (DEET), Rutgers 612 and Induline. There were (and are) two problems with a repellent applied to the skin-sweating it off and customer acceptance of an oily mixture. There is no way to evaluate the impact of skin repellents-or even their use. ${ }^{39}$

\footnotetext{
${ }^{34}$ Oliver R McCoy, 'War Department provisions for malaria control', in Preventive medicine in World War II, op. cit., note 1 above, pp. 11-22.

35 Russell, op. cit., note 27 above, p. 8-9.

${ }^{36}$ Emory C Cushing, History of entomology in World War II, Washington, DC, Smithsonian Institution, 1957, pp. 28-35; H L Haller and Stanley Cristol, 'The development of new insecticides', in E C Andrus, et al., Advances in military medicine, Boston, Little, Brown, 1948, vol. II, pp. 621-6; Harriet A
}

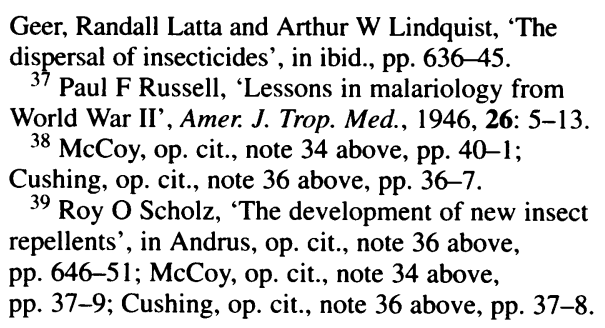


Malaria in American Troops in World War II

Table 2

Typical Malaria Control Organization

Unit

Personnel

Base Control Unit

Seabee/Army Engineer Battalion $\quad 292$

$\begin{array}{ll}\text { Natives } & 250\end{array}$

Troop Details $\quad 350$

Total

1,302

This is the organization required in 1944 to control malaria in 110 square miles of Guadalcanal.

(Source: Paul A Harper, et al., 'New Hebrides, Solomon Islands, Saint Mathias Group and Ryukyu Islands', in Medical Department, United States Army, Preventive medicine in World War II, vol. VI, eds John Coates and Ebbe C Hoff, Washington, DC, Office of the Surgeon General, USGPO, 1963, p. 446.)

Table 3

Southwest Pacific Pacific

\begin{tabular}{lcccc}
\hline & Feb. 1943 & April 1945 & Feb. 1943 & April 1945 \\
Malariologists & 7 & 24 & 6 & 15 \\
Survey Units & 3 & 34 & 4 & 18 \\
Control Units & 12 & 70 & 6 & 15 \\
\hline
\end{tabular}

The build up of malaria control organizations during the war.

(Source: Oliver T McCoy, 'War Department provisions for malaria control', in Medical Department, United States Army, Preventive medicine in World War II, vol. VI, eds John B Coates and Ebbe C Hoff, Washington, DC, Office of the Surgeon General, USGPO, 1963.)

\begin{abstract}
Atabrine
It is obvious that environmental control could not be performed in forward combat areas (including the use of bed nets). Even with clothing discipline, hands and faces were exposed, and repellent, even if used, was rapidly removed in the sweat. A prophylactic/suppressive drug was absolutely necessary for protection against malaria. Thus, the requirement was to examine prophylactic drug use and select the right drugs in the right doses and the correct times of administration. Quinine was used, when available, at Bataan, and initially at Buna and Guadalcanal. However, the Japanese conquest of Java meant that the source of 95 per cent of the world's quinine was no longer available. Further, prophylactic quinine had never been particularly successful in Asian hyperendemic areas in heavily infected people - which was the military problem.
\end{abstract}


Atabrine (mepacrine, quinacrine) and plasmoquine had been synthesized by German chemists from 1925 to 1932, as part of a programme begun after World War I during which Germany had been cut off from international sources of quinine. ${ }^{40}$ Atabrine had been tested in 1938 by American army investigators in soldiers in Panama for treatment. ${ }^{41}$ It had been found superior to quinine but had a side effect of turning the skin yellow and there were reports of gastrointestinal symptoms. As a prophylactic it had not been used for longer than a month, and the dosage and frequency had varied with each trial in studies conducted in $1934 .^{42}$

As new trials of atabrine began in 1942, there was concern that American and British manufacturing processes contained a toxic fraction not in the German product. (The Germans had not specified all the steps in their synthesis of the drug.) This was soon found not to be true, and clinical research began to study the dosage and timing of the use of the drug. ${ }^{43}$

Atabrine was administered sporadically on Guadalcanal and Buna in December 1942. There was no published doctrine for its use, nor any information on side effects. The unit medical officers thus invented their own programmes. These ranged from the daily use of 0.1 gramme to twice a week administration of 0.2 grammes, to 0.05 grammes for 5 days with 2 days of "rest". If a unit medical officer was successful with a particular regimen, in 1942 and early 1943 there was no system for reporting the data. ${ }^{44}$

Clearly, order needed to be established and hard data secured. In the United States, the Office of Scientific Research and Development supported studies in volunteers in prisons and among conscientious objectors. ${ }^{45}$ There was close co-ordination with elegant human trials done by Fairley at a research centre in Cairns, Australia. Here experimental malaria was transmitted to soldier volunteers by mosquito and by blood transfusion. Atabrine and other drugs were tested in varying protocols and volunteers were stressed by hard work to examine drug effect on possible breakthrough of symptoms while on drug prophylaxis. ${ }^{46}$ The American research was another of the new government-academia-industry consortia that had developed during the war. The malaria programme was exceptionally successful, especially in co-ordinating with international research programmes in Australia and Great Britain. ${ }^{47}$

The data from the co-ordinated programmes, primarily Fairley's conclusions (turned into Combined Advisory Committee directives in mid-1943), standardized the dose of atabrine at 0.1 gramme a day, with a one week "primer" before entering a malarial area. It was discovered that the dangerous falciparum was suppressed and, if atabrine was continued after leaving a malarial area, eradicated from the body, resulting in a cure.

\footnotetext{
${ }^{40}$ Pudney, op. cit., note 3 above.

${ }^{41}$ Cleon J Gentzhow and George R Callender, 'Malaria in the Panama Canal Department, United States Army. Results of treatment with quinine, atabrine and plasmodin', Amer. J. Hyg., 1938, 28: 174-89.

42 James S Simmons, Malaria in Panama, Baltimore, Johns Hopkins Press, 1939, p. 265, 268, 277; William H W Komp and H C Clark, 'A third year's observation on malaria in Panama, with special reference to control with atabrine', Amer. J. Trop. Med; 1934, 14: 381-406.
}

\footnotetext{
${ }^{43}$ George A Carden, Jr, 'Malaria: introduction', in Andrus, et al., op. cit., note 36 above, pp. 665-70.

${ }^{44}$ Harper, et al., op. cit., note 22 above, p. 469; The history of the Medical Department, op. cit., note 17 above, p. 162.

45 James A Shannon, 'The clinical testing of antimalarial drugs', in Andrus, et al., op. cit., note 36 above, pp. 698-716.

${ }^{46}$ N Hamilton Fairley, 'Chemotherapeutic suppression and prophylaxis in malaria', Trans. Roy. Soc. Trop. Med. Hyg., 1945, 38: 312-65.

${ }^{47}$ Condon-Rall, op. cit., note 31 above.
} 


\section{Malaria in American Troops in World War II}

Further, atabrine eliminated the sexual forms of falciparum (these are taken up by the mosquito bite and perpetuate the cycle, see note 3 ). Thus troops would not be reservoirs of infection for this species. ${ }^{48}$

The story was different with vivax. Atabrine would also suppress this form of malaria while the drug was taken, but it would not eliminate the organism. This was discovered when troops were removed from Guadalcanal, sent to non-malarial islands and suppressive atabrine withdrawn, “. . . in the hope of demalarializing [the division]. The theory was that if the troops were allowed to have their malaria, they would get it out of their system ... ". For example, the US Army Americal Division replaced the marines on Guadalcanal in early December 1942. Malaria discipline was poor to absent and the malaria rate was around 1,300/1000. The division was sent to Fiji, a non-malarious island, in March 1943, and atabrine was stopped. It was a disaster-the division came down en masse with vivax - by August the malaria rate was 3,700/1000/year and still at 2,800/1000 in October. Atabrine was begun in November-by January 1944 the rate was 43/1000. The division learned its lesson; in 5 months of combat on Bougainville the rate averaged $112 /$ month. ${ }^{49}$ In fairness to the medical staff, although a liver phase in avian malaria had been documented, it was not then known that vivax had a phase in man where it stayed in the liver and was not susceptible to drugs. This was suspected, but not proved until $1948 .{ }^{50}$

The first Marine Division after leaving Guadalcanal, and the US Army 32nd Division after withdrawal from Buna had similar experiences. These divisions were useless for combat for up to six months. ${ }^{51}$ It was these data that led General MacArthur to make his comment to Colonel Russell in May 1943.

The treatment of relapsed vivax malaria was not easily addressed. The sulfonamides, penicillin, and heavy metals were tried without success. Quinine was indifferently useful, while plasmochin (pamaquine) and totaquine and other cinchona alkaloids were of limited benefit. Long-term administration-for months - of atabrine prophylaxis appeared to offer the best results in patients with relapsed vivax. Atabrine was not without toxicity, although the incidence of side effects was quite low. The skin did turn yellow. An uncommon atabrine dermatitis complex (lichen planus) and a rare case of toxic psychosis did occur. All these signs and symptoms cleared on discontinuance of the drug. ${ }^{52}$

The research programmes in the United States eventually validated early German work on chloroquine for treatment and prophylaxis ${ }^{53}$ and developed the drug primaquine, still useful to eradicate the liver phase of vivax and thus prevent relapses. ${ }^{54}$ But during the war the only answer to vivax was continuous administration of atabrine. Millions of tablets were shipped-hundreds of thousands of pounds of the drug.

\footnotetext{
${ }^{48}$ Benjamin M Baker, 'The suppression of malaria', in Internal medicine in World War II, op. cit., note 5 above, pp. 465-77.

${ }^{49}$ Harper, et al., op. cit., note 22 above, p. 429.

${ }^{50} \mathrm{P}$ C C Garnham, 'History of discoveries of malaria parasites and their life cycles', Hist. Phil. Life Sci., 1988, 10: 93-108.

${ }^{51}$ Hart and Hardenbergh, op. cit., note 14 above, p. 568 .

${ }^{52}$ Harry Most, 'Clinical trials of antimalarial
}

drugs', in Internal medicine in World War II, op. cit., note 5 above, pp. 525-98.

53 G Robert Coatney, 'Pitfalls in a discovery: the chronicle of chloroquine,' Amer. J. Trop. Med. Hyg. 1963, 12: 12-8.

${ }^{54}$ Robert C Elderfield, 'The synthesis of antimalarial drugs', in Andrus, et al., op. cit., note 36 above, pp. 670-7. See also, Most, op. cit., note 52 above, pp. 594-8. 


\section{Conclusions}

Did all these command directions, research programmes and control efforts eventually work? In a word-yes. For the SWPA, for example, the malaria rate at Milne Bay in New Guinea in January 1943 was 3,300/1000/year; in January of 1944 it was 31/1000. For the entire command the February rate of $794 / 1000$ had fallen to $179 / 1000$ in February $1944 .{ }^{55}$ For the remainder of the war malaria rates would increase modestly during active combat, but never reached the disastrous levels of 1942 and 1943.

The major benefit of malaria control was, of course, the preservation of the health and lives of the soldiers and marines, permitting the prosecution of the war. Economically, the logistical and personnel support for hospital beds was markedly reduced. In the SWPA, intensive atabrine treatment reduced hospital stays from 15 to 6 days per patient. This reduction, coupled with the overall reduction in attack rates, forestalled the need for about an additional 10,000 hospital beds. ${ }^{56}$ The force multiplier of healthy troops kept in the line certainly hastened the defeat of the malaria ridden Japanese ${ }^{57}$ (see Table 4). But the

Table 4

US Marine Corps and US Navy malaria cases

\begin{tabular}{lr}
\hline New cases & 113,774 \\
Relapse cases & 89,507 \\
& \\
Total cases & 203,281 \\
& \\
Percentage relapsed & 78.6 \\
Percentage total to duty & 94.0 \\
\hline
\end{tabular}

These statistics are for the period 1942-1945.

(Source: The history of the Medical Department of the United States Navy in World War II, vol. 3, Washington, DC, USGPO, 1950, Table I, p. 92.)

medical research and control programmes would have meant nothing without the understanding, resources and discipline provided by line commanders, who supported and enforced the environmental and behaviour modification measures.

General Blaney, commanding the Australian army, put it succinctly in an interview reported by his malariologist in December 1942. He said in part, "No officer was fit to command in a hyperendemic malarial area who did not realize the menace of malaria, and take every step to prevent it". 58

\footnotetext{
55 Harper, et al., op. cit., note 22 above, p. 578.

${ }^{56}$ Hart and Hardenbergh, op. cit., note 14 above, pp. 572-8.

57 The official histories are: Robert $\mathrm{R}$ Smith, The approach to the Philippines, Washington, DC, Office of the Chief of Military History, USGPO, 1953; W Hamlin Cannon, Leyte: the return to the Philippines, Washington, DC, Office of the Chief of Military
}

History, USGPO, 1954, and Robert R Smith, Triumph in the Philippines, Washington, DC, Office of the Chief of Military History, USGPO, 1963. See also Allan Millet, Semper fidelis: the history of the United States Marine Corps, New York, Macmillan, 1980, pp. 344-441.

58 Walker, op. cit., note 1 above, p. 115. 
The best example is from another command, also riddled with malaria. Major General William Slim, commanding the British 14th Army in Burma wrote: "Good doctors are no use without good discipline." He described the introduction in 1943 of mepacrine [atabrine] and individual tests for taking the drug. "I, therefore, had surprise checks of whole units made, every man being examined. If the overall result was less than ninetyfive percent positive, I sacked the commanding officer. I only had to sack three; by then the rest had got my meaning". ${ }^{59}$ His malaria rates markedly decreased.

Lieutenant General Sir Neil Cantlie, who served in India as its senior British medical officer during the war and later became Director General of the British Army Medical Service put it very well. He reported a briefing by Fairley to commanders on malaria control: "One commander said: 'You doctors think you can prevent malaria, but you can't. I can and I am going to.' When for the first time in history a combatant officer was considered unfit to command on the grounds that he had allowed his men to become ineffective through disease, a new day in military medicine dawned." 60

\footnotetext{
${ }^{59}$ William Slim, Defeat into victory, London, Cassell, 1956, p. 180. For a modern analysis see Mark Harrison, 'Medicine and the culture of command: the case of malaria control in the British
}

\author{
Army during the two world wars', Med. Hist., 1996, \\ 40: 437-52. \\ ${ }^{60}$ Neil Cantlie, 'Health discipline', U.S. Armed \\ Forces med. J., 1950, 1: 232-8.
}

